УдК 94(470)

DOI 10.37386/2413-4481-2020-1-71-79

\title{
П.А. Афанасьев
}

\section{ДНЕВНИКИ Е.П. КЛЕВАКИНА КАК ЯВЛЕНИЕ ПИСЬМЕННОЙ КУЛЬТУРЫ РОССИЙСКОЙ ПРОВИНЦИИ ПОРЕФОРМЕННОЙ ЭПОХИ 1}

\begin{abstract}
Статья посвящена характеристике дневников провинциального чиновника Е.П. Клевакина, охватывающих 1864-1886 гг. Анализ количественных показателей интенсивности и регулярности дневниковых записей позволил выделить скачкообразность и прерывистость ведения их главными особенностями. Через интенсивность и полноту записей дается характеристика динамики понимания цели, содержания и значения дневников в жизни Е.П. Клевакина. Периоды всплеска интереса к дневникам отражали персонализированный процесс становления дневника классического типа, показывая постепенное раскрепощение личности их автора как человека пореформенной эпохи.

Ключевые слова: мемуаристика, дневники, эго-текст, Е.П. Клевакин, Урал, Пермь, Томск.
\end{abstract}

\section{P.A. Afanasiev \\ E.P. KLEVAKIN'S DIARIES AS A PHENOMENON OF WRITTEN CULTURE OF THE RUSSIAN PROVINCE OF THE POST-REFORM ERA}

\begin{abstract}
The article is devoted to the characteristics of a provincial official E.P. Klevakin's diaries, covering the years 1864-1886. The analysis of quantitative indicators of intensity and regularity of diary entries allowed to highlight their discontinuity as the main feature. Through intensity and completeness of records we characterize the dynamics of understanding of the purpose, contents and value of the diary in E.P. Klevakin's life. Periods of surge of interest in the diary reflected the personalized process of shaping a diary of the classical type, showing the gradual emancipation of the personality of their author as a person of the post-reform era.

Key words: memoirs, diaries, ego-text, E.P. Klevakin, Ural, Perm, Tomsk.
\end{abstract}

Развитие в исторических исследованиях направлений микроистории и истории повседневности неразрывно связано с выявлением и введением в научный оборот мемуаристики. Общепризнано, что она дает возможность представить и раскрыть исторические процессы, преломляя их через личный опыт отдельного человека, вписанного в контекст окружавшей его действительности. Наибольшую ценность с этой точки зрения представляют достаточно редкие примеры мемуарного творчества представителей социальных групп, не имевших устойчивой мемуарно-эпистолярной традиции, - мелкого и среднего чиновничества, торговцев, крестьян и других групп, проживавших преимущественно в провинции. Особое место в составе мемуаристики занимают дневники. Они неоднократно характеризовались как вид источника, в том числе в региональном сибирском контексте, с выделением присущих им признаков [1, с. 4-30; 2, с. 51-62]. В силу личного характера дневников нередко их авторы не желали делать свои записи достоянием посторонних глаз и тем более широких читательских кругов, что подчас затрудняет пополнение этой разновидности корпуса исторических источников. Такая ситуация острее преломляется по отношению к провинциальному населению. Не случайно Н.П. Матханова констатирует: «С большой долей уверенности можно говорить об утрате значительной части дневников жителей Сибири» [2, с. 58].

Поэтому без преувеличения уникальным можно назвать комплекс документов провинциального чиновника и общественного деятеля последней трети XIX - начала XX в. Евгения Поликарповича Клевакина, отложившийся в составе его личного фонда в Государственном архиве Алтайского края. Нехарактерной для рядового человека того времени являются высокая степень сохранности и видовое разнообразие созданных им документов. Помимо

\footnotetext{
${ }^{1}$ Публикация подготовлена при финансовой поддержке РФФИ, проект № 19-09-00448.
} 
недавно опубликованных обширных воспоминаний $[3,4]$ в их составе выделяются дневники. Дневниковые записи провинциальных чиновников не являются распространенным источником, несмотря на то, что из массы рядовых жителей именно эта социальная группа была наиболее привычна к письменному творчеству, обладая навыками культуры письма. Сам же Е.П. Клевакин как «человек пореформенной эпохи» за период ведения дневников осуществил значительный карьерно-социальный рост, воплотив в своей биографии возможности, открывшиеся после освободительной реформы и зависевшие от его личного выбора [5]. В связи с этим дневники Е.П. Клевакина представляют интерес как персонализированное воплощение видовых особенностей источника. Анализ этой проблематики в настоящей статье позволит раскрыть динамику дневникового творчества автора в контексте эволюции его личности как представителя пореформенной провинции.

Е.П. Клевакин вел дневники с 1864 по 1886 г. Большую часть этого времени автор жил на Урале. Выходец из мастеровых Кушвинского завода, после освобождения в 1861 г. Евгений Поликарпович остался служить по вольному найму на заводе, сменив несколько низших административных должностей. Поступив в 1866 г. на государственную службу, он занял конторскую должность смотрителя заводских припасов. Получение низшего классного чина открыло Е.П. Клевакину дорогу для постепенного служебного роста, начавшегося на бухгалтерских должностях в Кушвинском и Баранчинском заводах Гороблагодатского округа в 1874 г. Однако уже в 1875 г. по личным и служебным причинам он покинул горнозаводскую службу, уехав в губернский город Пермь, где поступил в губернское казначейство. Тяжелые материальные условия заставили его в конце 1875 г. окончательно оставить государственную службу и перейти вначале на частные заводы княгини Е.Х. Абамелек-Лазаревой (служил в 1876-1878 гг.), а затем в течение года быть приказчиком у купца В.Н. Бахарева. С 1879 по начало 1883 г. Е.П. Клевакин вновь был на государственной службе, в Пермской контрольной палате. Покинув ее и перейдя вновь к В.Н. Бахареву, в марте 1883 г. Е.П. Клевакин переехал в Томск, связав свою дальнейшую жизнь с Сибирью. После годичной службы в купеческой конторе, в 1884 г. Е.П. Клевакин вновь поступил на государственную службу. Вначале он был смотрителем Томского тюремного замка, а в 1885-1886 гг. занимал должность помощника полицейского исправника в Бийске [3, с. 4-47]. Насыщенная не только служебными перемещениями, но и сложными личными обстоятельствами жизнь
Е.П. Клевакина на протяжении всего периода сопровождалась ведением дневника.

По документам известно о четырех книгах дневников, написанных Е.П. Клевакиным [4, с. 430]. Однако до нашего времени сохранилось лишь три из них, дневник, охватывающий период с конца 1875 г. по конец 1881 г., оказался утерянным [4, с. 441; 6, с. 345]. Оставшиеся дневники представляют собой книги для записей в твердых переплетах размерами около $22 x 36$ см. В каждой из них автором были пронумерованы листы, с левой стороны каждой страницы сделан отступ поля, в котором указывалась дата записи и при необходимости делались пометы. Наряду с дневниковыми записями в книгах, как правило, в их конце Е.П. Клевакин вел счета прихода и расхода денег, расчеты с разными лицами. Но эти записи никогда не были привязаны к датам дневника, составляя самостоятельные части в книгах.

Несмотря на значительный хронологический промежуток, дневниковые записи не заполняют его равномерным сплошным охватом. Интенсивность дневниковых записей в пределах каждого года и их объем распределяются очень неравномерно по всему периоду их ведения. Подготовка рукописей к публикации дала возможность точных количественных подсчетов, характеризующих дневники. Сводные данные об этом представлены в таблице 1.

Можно говорить, что у Е.П. Клевакина не сложилось устойчивой традиции и потребности систематического ведения дневника. Об этом ярко свидетельствуют данные за первые годы. Высокая частота записей и их достаточный объем за первый год могут объясняться интересом автора к новому для него времяпрепровождению. Однако в два следующих года обращение к дневнику резко сокращается, и только в 1868-1869 гг. вновь наблюдается всплеск интереса к ведению дневника. В целом первая книга дневника, охватывая 7 лет и почти половину всех дней ведения записей, в общем объеме текста дневников занимает около 15 \%. Основной объем дневниковых записей сосредоточен во второй книге, преимущественно за 1875 г., хотя первый год записей в новой книге и полное отсутствие записей в 1872 г. полностью укладываются в тенденцию первой книги. Третья книга, охватывая полные 4,5 года, по интенсивности записей существенно уступает даже первой книге дневника. При этом сами записи становятся объемнее, благодаря чему в общей информативно-содержательной картине дневников Е.П. Клевакина их третья книга занимает ровно треть от всего объема.

Сводные данные, представленные в таблице 1, дают также возможность предположительно опре- 
делить интенсивность и объем записей в утраченной книге дневника за конец 1875 - конец 1881 гг. Вероятно, в начале ее ведения эти показатели не уступали данным последних месяцев 1875 г., потом превратившись в нерегулярное внесение записей, но объемных по своему содержанию. Об- щее количество листов в утраченной книге (142) с учетом особенностей заполнения дневниковых книг Е.П. Клевакиным позволяет предположить, что объем и содержательное наполнение записей в ней были, скорее всего, сопоставимы со второй книгой дневника.

Таблица 1

Сведения о годовых объемах и интенсивности записей в дневниках Е.П. Клевакина

\begin{tabular}{|c|c|c|c|c|c|c|c|}
\hline $\begin{array}{c}\text { Книга } \\
\text { дневника }\end{array}$ & $\begin{array}{c}\text { Год } \\
\text { записей }\end{array}$ & $\begin{array}{c}\text { Число } \\
\text { месяцев } \\
\text { с записями }\end{array}$ & $\begin{array}{c}\text { Число } \\
\text { дней } \\
\text { записей }\end{array}$ & $\begin{array}{c}\text { Объем } \\
\text { записей, } \\
\text { знаков }\end{array}$ & $\begin{array}{c}\text { \% дней } \\
\text { с записями } \\
\text { от общего } \\
\text { числа дней } \\
\text { за годы } \\
\text { ведения } \\
\text { дневников } \\
\end{array}$ & $\begin{array}{c}\text { \% объема } \\
\text { записей } \\
\text { от объема } \\
\text { книги } \\
\text { дневника }\end{array}$ & $\begin{array}{c}\text { \% объема } \\
\text { записей } \\
\text { от общего } \\
\text { объема } \\
\text { дневников }\end{array}$ \\
\hline \multirow{7}{*}{ Книга 1} & 1864 & 3 & 40 & 17342 & 21,74 & 18,71 & 2,73 \\
\hline & 1865 & 2 & 7 & 2565 & 1,92 & 2,77 & 0,40 \\
\hline & 1866 & 4 & 33 & 4181 & 9,04 & 4,51 & 0,66 \\
\hline & 1867 & 3 & 53 & 3640 & 14,52 & 3,93 & 0,57 \\
\hline & 1868 & 7 & 47 & 15552 & 12,84 & 16,78 & 2,45 \\
\hline & 1869 & 9 & 58 & 45805 & 15,89 & 49,42 & 7,22 \\
\hline & 1870 & 3 & 4 & 3601 & 1,10 & 3,89 & 0,57 \\
\hline \multirow{4}{*}{ Книга 2} & 1871 & 7 & 13 & 9802 & 3,56 & 2,99 & 1,54 \\
\hline & 1873 & 5 & 34 & 42954 & 9,32 & 13,12 & 6,77 \\
\hline & 1874 & 5 & 6 & 14843 & 1,64 & 4,53 & 2,34 \\
\hline & 1875 & 9 & 99 & 259749 & 28,45 & 79,35 & 40,94 \\
\hline \multirow{6}{*}{ Книга 3} & 1881 & 2 & 4 & 11979 & 10,00 & 5,59 & 1,89 \\
\hline & 1882 & 5 & 15 & 55208 & 4,11 & 25,74 & 8,70 \\
\hline & 1883 & 6 & 22 & 113049 & 6,03 & 52,71 & 17,82 \\
\hline & 1884 & 3 & 5 & 15114 & 1,37 & 7,05 & 2,38 \\
\hline & 1885 & 4 & 7 & 16219 & 1,92 & 7,56 & 2,56 \\
\hline & 1886 & 2 & 2 & 2903 & 1,22 & 1,35 & 0,46 \\
\hline \multicolumn{2}{|c|}{ Итого по книге 1} & 31 & 242 & 92686 & 10,19 & - & 14,61 \\
\hline \multicolumn{2}{|c|}{ Итого по книге 2} & 26 & 152 & 327348 & 27,3 & - & 51,59 \\
\hline \multicolumn{2}{|c|}{ Итого по книге 3} & 22 & 55 & 214472 & 3,003 & - & 33,80 \\
\hline \multicolumn{2}{|l|}{ Итого } & 79 & 449 & 634506 & 8,19 & - & 100 \\
\hline
\end{tabular}

Подсчитано по: [7-9].

Интерес к ведению дневника у Е.П. Клевакина проявлялся резкими всплесками. Период наивысшей активности записей пришелся на 1875 г., что вполне объяснимо сменой службы, переездом в Пермь и временным расставанием автора с семьей. Второй всплеск записей относится к 1883 г., что, вероятно, было вызвано подготовкой и переездом в Сибирь. Третий всплеск дневниковой активности автора примыкает к предыдущему, начиная его и являясь временем после смерти жены Е.П. Клевакина. Немного менее активны по записям были всплески интереса к дневнику в 1869 и 1873 гг., объяснение которым внешние события жизни автора не дают.
Детализация объема и интенсивности записей по каждому месяцу дневника приведена в таблице 2. В нее включены только те месяцы (26), объем записи в которых превышал 1 \% от общего объема дневников. Интенсивные и регулярные записи, охватывавшие более половины дней месяца, характерны только для 7 из них. Из более 15-летнего срока половина всех записей сделана в течение всего лишь 8 месяцев (99 дней), большинство которых относится к 1875 г. Следующая четверть объема всех записей велась заметно менее активно и не так интенсивно, охватив уже 12 месяцев (127 дней). Записи из этой группы производились во все выделенные выше периоды активного ведения дневника. Сведе- 
ния о не включенных в таблицу месяцах позволяют посчитать, что эта большая часть месяцев ведения дневника (2/3 или 53 месяца) была представлена редким охватом дней и очень краткими по объему записями. В целом анализ таблицы 2 убедительно подтверждает вывод о ярко выраженном прерывистом и скачкообразном характере ведения дневника.

Таблица 2

Распределение записей дневников Е.П. Клевакина по месяцам в порядке убывания объема

\begin{tabular}{|c|c|c|c|}
\hline Год и месяц & $\begin{array}{c}\text { Кол-во } \\
\text { дней } \\
\text { записей }\end{array}$ & $\begin{array}{c}\text { Объем } \\
\text { записи, } \\
\text { знаков }\end{array}$ & $\begin{array}{c}\text { \% объема } \\
\text { записей от } \\
\text { общего } \\
\text { объема } \\
\text { дневника }\end{array}$ \\
\hline 1875 , сентябрь & 21 & 63922 & 10,07 \\
\hline 1875, октябрь & 24 & 56073 & 8,84 \\
\hline 1875, декабрь & 12 & 39476 & 6,22 \\
\hline 1883, март & 4 & 38224 & 6,02 \\
\hline 1875, ноябрь & 18 & 37970 & 5,98 \\
\hline 1883, апрель & 6 & 29780 & 4,69 \\
\hline 1883, январь & 7 & 26159 & 4,12 \\
\hline 1875, апрель & 7 & 25925 & 4,09 \\
\hline 1882, октябрь & 4 & 24391 & 3,84 \\
\hline 1875 , август & 9 & 19348 & 3,05 \\
\hline 1869, февраль & 15 & 14104 & 2,22 \\
\hline 1873, декабрь & 9 & 14062 & 2,22 \\
\hline 1882, апрель & 3 & 13060 & 2,06 \\
\hline 1869, март & 20 & 12341 & 1,94 \\
\hline 1868, ноябрь & 15 & 11988 & 1,89 \\
\hline 1873, сентябрь & 10 & 11841 & 1,87 \\
\hline 1875, июль & 5 & 11558 & 1,82 \\
\hline 1883, февраль & 2 & 10825 & 1,71 \\
\hline 1873, ноябрь & 8 & 10675 & 1,68 \\
\hline 1864, июль & 27 & 10493 & 1,65 \\
\hline 1885, март & 2 & 9326 & 1,47 \\
\hline 1882, ноябрь & 3 & 8666 & 1,37 \\
\hline 1869, апрель & 13 & 8410 & 1,33 \\
\hline 1884, апрель & 3 & 8376 & 1,32 \\
\hline 1881, декабрь & 2 & 7660 & 1,21 \\
\hline 1882, январь & 4 & 7653 & 1,21 \\
\hline Итого по 1 группе & 99 & 317529 & 50,03 \\
\hline Итого по 2 группе & 127 & 164686 & 25,95 \\
\hline Итого по 3 группе & 27 & 50091 & 7,91 \\
\hline Итого по таблице & 253 & 532306 & 83,89 \\
\hline Не включено & 196 & 102200 & 16,11 \\
\hline
\end{tabular}

Подсчитано по: [7-9].
Среди причин нерегулярного ведения дневника Е.П. Клевакиным можно назвать нехватку времени для этого занятия. В конце 1860-х - начале 1870-х гг. свободное время автор занимал «зимой чтением, а летом путешествием по окрестностям или с ружьем, или просто так, без всего». К тому же много времени отнимало ведение хозяйства. Оказавшись в 1875 г. в Перми, Е.П. Клевакин отмечал: «Как буду служить, так и дневник прийдется писать много менее» [8, л. 72 об.]. Дежурные дни, поздние возвращения домой зачастую не оставляли времени для записи. Позже в Бийске к служебной занятости добавилось увлечение Евгения Поликарповича карточными играми, которые, видимо, также оставляли мало времени для ведения дневника. Но только занятость автора вряд ли объясняет неравномерность ведения продолжительных по времени дневников. Попытки объяснения этой специфики заставляют пристальнее взглянуть на причины их ведения и место в жизни автора.

Дневники Е.П. Клевакина являются первыми по времени создания из всего комплекса сохранившихся документов автора. Начиная записи 1 июля 1864 г., он объяснил это своим давним желанием, которому препятствовала лень. В сознании автора дневник, очевидно, ассоциировался с фиксацией каких-либо заметных или выдающихся событий в жизни и окружающей обстановке. Неслучайно в самом начале он отметил: «Хотел, было, завести я дневник свой с замечательного какого-нибудь события (своего), случившегося со мной, но все событий нет, то хоть начну с первого числа» [7, л. 1]. Но четкого понимания, что нужно фиксировать в дневнике, у Евгения Поликарповича, по-видимому, не имелось. Уже через 10 дней после начала записей он отметил: «Особенного ничего» [7, л. 4]. В записях первого года ведения дневника встречаются указания погоды, перечисления дел автора, его участие в каких-либо общественных мероприятиях. При этом Евгений Поликарпович избегал описаний обстоятельств личной жизни или ограничивался краткими упоминаниями общего характера. К примеру, его ремарка от 7 августа 1864 г. «Ходил кое-куда» не поясняется дальнейшим повествованием [7, л. 8 об.]. Женитьба Е.П. Клевакина также осталась за пределами дневника. О дате этого события он записал только через полгода, 12 апреля 1865 г., не описывая никаких подробностей [7, л. 12]. Даже о поездке по служебному поручению в Нижний Тагил автор больше сообщил в позднейших воспоминаниях, чем в дневнике [3, с. 167-168; 7, л. 9 об.]. Скорее всего, в начальный период ведения дневника автор вряд ли рассматривал его как место, в котором можно фиксировать глубоко личные впечатления. Объяснение 
В.А. Кошелевым отсутствия мемуаров крестьян их неспособностью «осознать важность и особенную ценность собственной жизни и собственной личности» [2, с. 122], видимо, в начале ведения дневника применимо и к Е.П. Клевакину, выходцу из низших слоев общества. Поэтому дневник не стал для него душевным «собеседником», что свидетельствовало о несформированной потребности ведения такой формы записей. «День прошел обыкновенно» [7, л. 4 об.] так можно определить общий характер содержания дневника Е.П. Клевакина в первый год после его начала.

В апреле 1865 г. записи в дневник прекратились почти на год, возобновившись в мае 1866 г. Однако теперь это были лишь краткие записи погоды наблюдательно-субъективного характера. Но и они не стали систематическими. Терпения автора при их ведении хватало не более чем на полтора месяца. После почти месячной фиксации погоды в сентябре 1866 г., Е.П. Клевакин вновь вернулся к этой форме дневниковых записей только в апреле-июне 1867 г., а затем в мае 1868 г. Изредка эти заметки перемежались единичными вкраплениями каких-либо событий. Именно в записях о погоде в дневнике впервые появляется ремарка о прекращении записей (сентябрь 1866 г.): «Вести журнал о погоде трудновато, а потому его и брошу» [7, л. 15 об.]. Очевидно, трудность для автора состояла не в самом характере очень простых и кратких записей, а в необходимости их ежедневной фиксации. Поэтому наряду с несложившимися критериями отбора информации для дневника, спорадичность и краткость записей вполне объяснялась отсутствием у его автора терпения к регулярным записям. Можно говорить, что у Е.П. Клевакина в первые годы записей еще не сформировалась культура ведения дневника. Косвенно это подтверждает отсутствие в первой книге дневника замечаний автора о причинах прекращения или возобновления записей (за исключением цитированного случая), а также объяснений длинных перерывов между записями.

Еще одна причина нерегулярности и краткости дневниковых записей в первые годы кроется в характере их ведения. Первую книгу дневника, скоpeе, можно назвать «книгой для записи», поскольку наряду с дневниковыми статьями она содержит и другие материалы. В их числе различные счета денежных расходов и долгов, рисунки предполагаемых автором построек и их расчеты, записи результатов охоты и иные записи хозяйственного содержания. Все эти материалы расположены в книге бессистемно. Некоторые дневниковые записи по форме также напоминают «записки для памяти», соответствуя общему характеру книги. Таковы, например, выписки из газет с анонсами новых изданий или условиями подписки. Тем не менее изначально книга предназначалась для дневника, записи в который, начиная с первого листа, осуществлялись последовательно, хотя и могли разрываться посторонними материалами, продолжаясь на следующем за ними чистом листе. Иногда записи помещались на любом свободном месте в книге. Так, очевидно, в августе 1868 г. появилась фиксация приезда в Кушвинский завод великого князя Владимира Александровича. Это единственная запись за август 1868 г. по почерку и месту расположения производит впечатление случайной и сделанной только в силу значимости события [7, л. 29 об.].

Возможно, что «разбросанный» характер дневниковых записей вперемешку с другими материалами не способствовал регулярному и тематически однородному ведению дневника. Но уже во второй и третьей книгах дневника внутренняя пестрота исчезает. Во второй книге несколько листов ближе к концу, видимо, изначально было оставлено автором для записи счета прихода и расхода денег и различных материалов. Хотя не все зарезервированные листы были заполнены, тем не менее они остались свободны и от дневниковых записей. В последней книге последние листы также отводились для различных счетов. Примечательно, что записи во второй и третьей книгах сам автор в ходе изложения материала часто называет дневником, чего не наблюдалось в первой книге, за исключением начальной записи. Это нашло отражение и в формальной стороне оформления второй и третьей книг. На их первых листах Е.П. Клевакин, очевидно, после заполнения книг записями, сделал оглавления. В них дневниковые записи уже четко отделены самим автором от иных материалов. Во второй книге они озаглавлены «Мемуар», в третьей - «Дневник» $[8$, л. $1 ; 9$, л. 1]. Налицо видно стремление самого автора к формальному обособлению дневников от иных записей повседневного содержания.

Установившееся содержательное единообразие второй и третьей дневниковых книг было связано с тем, что Е.П. Клевакин одновременно вел записи и в других книгах. Так, из дневника 1875 г. известно о наличии у него «памятной книжки», в которой оставляли записи его знакомые, а также сам Евгений Поликарпович делал какие-либо разрозненные заметки случайного или малозначимого характера [8, л. 89]. Таких книжек у него, видимо, было несколько, и по мере заполнения записями они выбрасывались. Именно в них он теперь производил «вседневную запись» погоды (по крайней мере, в 1879-1882 гг.), позже переписав ее в отдельный журнал [10, л. 25 об.-43]. Также в 1875 г. у Е.П. Клевакина были какие-то «за- 
писки о охоте, рыбной ловле и о пашне» [8, л. 102 об.]. Возможно, что так он назвал первую книгу своего дневника, обособляя ее от текущей второй книги. Не исключено также, что подобным наименованием автор сознательно отделял дневниковые записи первой книги от иных ее материалов, представляя их как совершенно разные тексты, лишь формально объединенные в одном переплете. Не случайно, в этой же записи автор отделяет дневник от названных записок, включив его в общий перечень показанных своему собеседнику материалов. Характерно, что третья книга дневниковых записей имеет авторский заголовок, написанный на обороте обложки: «Книга на записку разной разности на память с 1881 октября», хотя дневник в ней занимает главное место. Уже позже, в Бийске, Евгений Поликарпович завел отдельные журналы для записи охотничьих рассказов и так называемую «книгу оригинальностей». Все это в итоге способствовало приданию дневникам единообразия в записях.

С 1 ноября 1868 г. характер ведения дневниковых записей заметно изменился. Е.П. Клевакин теперь старался делать подробные фиксации значимых событий, происходивших с ним или его окружением. Благодаря этому дневниковые статьи наполняются повседневными деталями. Подробные записи также охватили февраль, март и апрель 1869 г., после чего продолжались с гораздо меньшей интенсивностью. В целом записи конца 1868-1869 гг. составляют почти половину всей первой книги дневника. Однако непонятны причины столь резкого изменения подхода Е.П. Клевакина к ведению дневника. Судя по записям, автор достаточно времени уделял чтению книг и газет, что могло влиять на формирование потребности осмысливать не только прочитанное, но и переживаемое в повседневной жизни. Гораздо позже он отмечал в дневнике: «Чтение... больше всего научает распознавать жизнь» [8, л. 117]. Возможно, что оказывала воздействие возрастающая жизненная самостоятельность Евгения Поликарповича, выражавшаяся в заведении собственного хозяйства, обеспечении растущей семьи. Неслучайно именно в 1869 г. в дневнике появляются хозяйственные заметки, связанные с предполагавшимся строительством дома, сенокосом, пашнями и т. д. Дневник, видимо, стал отражать более осмысленное отношение автора к жизни с необходимостью рефлексии важнейших событий окружавшей повседневности. Можно сказать, что эти записи свидетельствуют о становлении дневника в классическом понимании, с фиксацией событий, авторских мыслей и переживаний. Однако такое внимание автора к дневнику едва продержалось до конца 1869 г., в следующем году было сделано всего четыре записи.
Новая книга дневника, начатая в январе 1871 г., по характеру не отличалась от записей конца 1868-1869 гг. Но обращения к дневнику стали очень редкими: за январь 1871 г. было сделано 4 записи, далее же по 1-2 записи в месяц. Именно в это время у Е.П. Клевакина появляется осознание правильности ведения дневника. В записи от 4 мая 1871 г. (6 запись с начала года) автор с горечью писал: «Сколько раз я начинал вести свой дневник и все не могу продолжать долго, а каких-нибудь пройдет неделя, другая, я уже и остыл, и теперь не знаю, состоится ли мое намерение» [8, л. 3 об.]. Таким образом, ведение дневника для Евгения Поликарповича становилось уже осознаваемой потребностью. Тем не менее она не получала систематической реализации из-за посторонних занятий («глупостей»), наполнявших жизнь автора и периодически вызывавших его раздражение. Поэтому в дневнике Евгений Поликарпович едва ли не впервые откровенно записал свою жизненную установку на ближайшее время: «Пора приняться за дело, пора вести жизнь более правильную, пора бросить все глупости» [8, л. 3 об.]. В контексте следующей за этим записи дневник, видимо, воспринимался автором как один из способов проявления твердости характера. Однако достичь регулярного ведения дневника автору так и не удалось. Более того, в 1872 г. впервые за 8 лет не было сделано никаких дневниковых записей. Такая ситуация продлилась полтора года вплоть до августа 1873 г.

Новое обращение к записям Е.П. Клевакин предварил словами: «Опять принимаюсь за дневник» $[8$, л. 7], чем сознательно отделил его от предшествующих заметок. Однако внесение записей автор ставил в зависимость от каких-то личных обстоятельств, доверить которые бумаге он не решился: «После увижу, что случится, и тогда могу писать уже в силу обстоятельств» [8, л. 7]. Тем не менее последующие записи 1873 г. характеризовались объемом, сопоставимым с 1869 г. По характеру записи вновь были похожи на «классический» дневник. Очередной этап эволюции дневника в этом направлении, скорее всего, был связан с влиянием на Е.П. Клевакина книги С. Смайлса «Самодеятельность». Неслучайно теперь автор отмечал в дневнике свое желание жить и работать «поновому», "стараться вести свои дела аккуратно», распространяя также понравившиеся ему идеи среди окружения [8, л. 17 об.]. Помимо фиксации событий, в дневнике автор также анализировал поступки свои и окружающих, пытаясь давать им нравственную оценку. Все это помещалось в контекст каких-то событий, попадавших на страницы дневника. Именно записи 1873 г. свидетельствуют 
об окончательном становлении той модели дневника, которая удовлетворяла Е.П. Клевакина и, очевидно, была ему необходима.

С 1873 г. заметной становится еще одна особенность дневника: Е.П. Клевакин все чаще обращался к записям преимущественно в трудные периоды жизни. Дневник стал для автора отдушиной, где он мог выразить свои мысли и чувства. Эта особенность вышла на первый план осенью 1875 г., в наиболее тяжелое для Е.П. Клевакина время, когда он вынужденно оставил горнозаводскую службу и переехал в Пермь, для экономии средств оставив семью в Кушве. Поэтому дневник превратился для Евгения Поликарповича в своеобразного «собеседника», которому автор доверял все события своей жизни и раскрывал свой внутренний мир. Ведение записей было также способом времяпрепровождения. «Одному скучно. Да еще меня много развлекает писание дневника» [8, л. 81 об.], - отмечал автор. Судя по дневнику, Е.П. Клевакин в период с сентября по декабрь 1875 г. уделял записям едва ли не большую часть свободного времени. Не имея иногда возможности сделать записи, он стал особо отмечать это, объясняя причины таких пропусков. Поэтому ведение дневника можно считать и определенным способом самодисциплины, которая была необходима Е.П. Клевакину для непростого выживания в Перми. Однако благодаря трудному жизненному периоду и временному одиночеству автора, дневниковые записи сентября - декабря 1875 г. отличаются наибольшей подробностью описаний. Записи этого периода составляют абсолютное большинство второй книги дневника, преобладая также и в общем объеме дневников.

Утрата следующей книги дневника не дает даже возможности предположить, как долго сохранялся такой детальный и систематический характер записей. Завершающая фраза второй книги «Переношу дневник в другую книгу» [8, л. 137 об.], а также первая фраза следующей сохранившейся книги «Начинаю записывать в новую книгу свои мысли, заметки и события жизни» [9, л. 2] позволяют предполагать, что ведение дневника для Е.П. Клевакина стало осознанной потребностью. О регулярности записей можно судить лишь предположительно. Сохранились наблюдения Е.П. Клевакина о погоде, которые он вел на всем протяжении второго периода пермской жизни, с 9 апреля 1879 г. по октябрь 1882 г. Эти заметки отличаются заметным постоянством [10, л. 25 об.-43]. Сопоставление совпадающих промежутков погодных наблюдений и третьей книги дневника (1881-1882 гт.) показывает, что даты редких дневниковых записей никак не соотносились с достаточно частой фиксацией погоды. Поэтому можно предполагать, что записи в утраченной книге дневника также вряд ли носили регулярный характер.

Третья из сохранившихся книг дневника в первые годы ведения по характеру записей мало отличается от записей 1873-1875 гг. Заметно лишь резкое снижение частоты записей, но сами они становятся более обширными. Отчасти это связано с тем, что в записях 1882 г. Е.П. Клевакин описывал не только текущие события, но и восстанавливал прошедшие несколько месяцев назад обстоятельства болезни и смерти жены. Тяготение в сторону воспоминаний стало одной из черт дневниковых записей 1883-1884 г. К примеру, путевые впечатления от переезда из Перми в Томск Е.П. Клевакин записал уже после приезда. Также уже по итогам событий он описал свое назначение на должность в Бийск. Тем не менее восстановление в дневнике прошедших событий не превратилось в основной метод. Сетуя не раз в 1883-1885 гг. на ставшие редкими обращения к записям, Е.П. Клевакин сознательно отказывался от восполнения пропущенного времени событиями: «Давно ничего не писал в дневник, а есть чего писать. Много разной разности можно бы и должно записать, но не записал, так уже прошлого не воротишь» $[9$, л. 61].

Заметное ослабление внимания автора к дневнику с 1884 г. было, скорее всего, связано с освоением автором новых форм для своих письменных занятий. В 1884 г. это воплотилось в составлении «Материалов для записок смотрителя Томского тюремного замка». Они хотя и напоминают дневник с обозначением дат записей, но тяготение к тематическому изложению приводило к нарушению синхронности указанных дат с описанными событиями. Е.П. Клевакин выстраивал «Материалы» как самостоятельное произведение, создавая их в расчете на публикацию и массового читателя [3, с. 70]. Уже в Бийске Евгению Поликарповичу «пришло на мысль записать все слышанное, виденное, а также и такое, где я сам участвовал, наиболее оригинальное» [9, л. 61]. Результатом этого стали специально заведенные им отдельные журнал записей «Случаи из жизни охотников» и «Книга оригинальностей» с включением в них различных историй и рассказов, взятых Е.П. Клевакиным из своей жизни. По характеру они больше походили на воспоминания. Такая «побочная» писательская активность, видимо, не оставляла достаточного времени для дневника. Е.П. Клевакин сам заметил ослабление своего интереса к его ведению, отметив в апреле 1884 г.: «Посмотрел свой дневник и оказалось, что очень мало я записываю. Надо бы больше записывать и наблюдать окружающую меня жизнь, а я только и записываю, что относится близко к моей персоне» $[9$, л. 57]. Как ни странно, но имен- 
но после этой записи интенсивность обращения к дневнику резко снизилась.

Увлечение Е.П. Клевакина новыми формами записей, скорее всего, было результатом ослабления удовлетворенностью от дневника, что привело к затуханию и прекращению его ведения. Ограничивая рамками описываемого дня, он не позволял делать широкие описания и обобщения, к которым все более тяготел автор. С начала 1880-х гг. Евгений Поликарпович не раз упоминал о желании писать корреспонденции в газеты [9, л. 2, 25 об.], демонстрируя этим стремление к сюжетно завершенным повествованиям, которым дневник мало соответствовал. Не случайно записи о жизни в Бийске Е.П. Клевакин делал не в книге дневника, в которой еще оставалось много чистых страниц, а на отдельных листах, с самостоятельными заголовками, хотя и с указанием дат записей, близких к описываемым событиям. Это также свидетельствует о сознательном отказе Е.П. Клевакина от ведения дневника. Последняя запись была сделана 13 июня 1886 г., после которой не было никаких отметок о прекращении дневника. Оставшиеся чистые листы в книге были затем вырезаны.

Е.П. Клевакин рассматривал дневник как глубоко личное явление. Свои записи он старался никому не показывать, соблюдая, «чтобы дневник мой не попал в посторонние руки» [8, л. 74 об.-75]. Опасаясь этого, автор переживал, что чтение дневниковых записей чужими людьми может вызвать неправильное восприятие его личности и оценку характера: «Вот если мой дневник попадет комунибудь в посторонние руки и будет прочитан, то-то посмеются надо мной» [8, л. 74 об.]. Правда, в редких случаях автор был вынужден демонстрировать дневник знакомым. «Пришлось показать Ивану Ивановичу мой дневник» [8, л. 102 об.], - отметил Е.П. Клевакин 28 октября 1875 г. Записи в дневник Евгений Поликарпович делал для себя, позже не раз перечитывая их [8, л. 81 об.]. Какие-то записи Е.П. Клевакина читались в кругу семьи, но вряд ли дневник входил в их число. В первую очередь автор рассчитывал оставить дневники своим потомкам, отмечая: «Что подумают мои потомки, для которых я пишу этот дневник» [8, л. 81 об.]. Наиболее вероятным читателем дневников Е.П. Клевакин видел своего сына Петра, которому он намеревался дать их для прочтения уже в зрелом возрасте [8, л. 98 об.]. Однако личный характер дневников и их нацеленность только на передачу своим потомкам приходили в противоречие с желанием Е.П. Клевакина быть известным в обществе. В какой-то степени это тоже сказалось на прекращении ведения дневника и переходе автора к написанию корреспонденций, рассказов и воспоминаний, готовившихся уже в расчете на публикацию и широкий круг читателей.

Итак, дневники Е.П. Клевакина, охватывающие продолжительный период времени, нельзя назвать однородным источником. Их главная характеристика - внешняя скачкообразность ведения, выражавшаяся во всплесках интереса автора к осуществлению записей, перемежавшихся длительными периодами невнимания и порой полного забвения дневника. Подтверждающие это количественные показатели интенсивности дневниковых записей полностью опровергают впечатление, производимое внешне значительным охватом времени всех дневников. Но прерывистость и нестабильность ведения дневников являются всего лишь ширмой, скрывающей от поверхностного взгляда их глубинные характеристики. Некоторые из них (цель записей, их состав и содержание) претерпевали изменения вследствие все более четкого их понимания самим автором. За всплесками активности записей можно увидеть процесс становления дневника классического типа, а также все более увеличивавшуюся тесную взаимосвязь записей с личностью и душевными переживаниями автора. С другой стороны, эволюция дневников Е.П. Клевакина во многом была связана с традициями той окружающей среды, в которой оказывался автор в разные периоды жизни. В целом это неудивительно для любого дневника. Но в случае с Е.П. Клевакиным, вышедшим из зависимого состояния, эволюция видовых особенностей его дневников, помимо содержательной стороны, отражала постепенное раскрепощение личности их автора как человека пореформенной эпохи. Поэтому неслучайно, что к середине 1870-х гг. записи не только наполняются авторской рефлексией, но и становятся для него необходимыми, особенно в трудные периоды жизни. В этом контексте несистематичное ведение дневника со временем приобретает совершенно иной характер: «писательские желания» автора перерастают рамки дневника, в конце концов, приводя к его прекращению. В итоге дневники Е.П. Клевакина оказываются глубоко персонализированным эго-текстом, в котором интенсивность и объем их ведения становятся определяющей характеристикой-оболочкой, влияющей на понимание автором места дневников в его жизни и содержательную насыщенность, определяющую их значимость как исторического источника. Подобное преломление видовых особенностей источника через биографический путь его автора делает дневники Е.П. Клевакина интересным памятником провинциальной письменной культуры и мемуарной традиции пореформенной России. 


\section{Библиографический список}

1. Михеев М. Ю. Дневник как эго-текст (Россия, XIX-XX). М.: Водолей Publishers, 2007. 262 с.

2. Матханова Н. П. Сибирская мемуаристика XIX века. Новосибирск: Изд-во СО РАН, 2010. 551 с.

3. Клевакин Е. П. Записки провинциального чиновника второй половины XIX века: Воспоминания и рассказы о жизни и службе на Урале и Алтае: сборник документов: в 2 т. / изд. подгот. П. А. Афанасьев. Барнаул: АлтГПУ, 2017. T. 1. 420 с.

4. Клевакин Е. П. Записки провинциального чиновника второй половины XIX века: Воспоминания и рассказы о жизни и службе на Урале и Алтае: сборник документов: в 2 т. / изд. подгот. П. А. Афанасьев. Барнаул: АлтГПУ, 2017. T. 2. 458 c.

5. Афанасьев П. А. Е. П. Клевакин: провинциальный чиновник на фоне пореформенной эпохи // Исторический курьер. 2018. № 2. URL: http://istkurier.ru/data/2018/ISTKURIER-2018-2-03.pdf.

6. Афанасьев П. А. История личного фонда Е. П. Клевакина в Государственном архиве Алтайского края // Гуляевские чтения. Барнаул, 2018. Вып. 4. С. 341-345.

7. Государственный архив Алтайского края (ГААК). Ф. 77. Оп. 1. Д. 6.

8. ГААК. Ф. 77. Оп. 1. Д. 24.

9. ГААК. Ф. 77. Оп. 1. Д. 25.

10. ГААК. Ф. 77. Оп. 1. Д. 14. 